\title{
The Development Of Project-Based Books In Media Learning Lesson To Improve The Ability Of Learning Students In Major Of Special Education
}

\author{
Zaini Sudarto \\ Universitas Negeri Surabaya \\ Surabaya, Indonesia \\ zaini_sudarto@gmail.com
}

\begin{abstract}
This study aims to develop a proper and effective project-based textbook to improve students in learning the outcome. This study used Dick and Carey developmental model. Data were collected through structured interview, questionnaire, and test. the structured interview was used to determine the level of eligibility of textbooks developed by media expert, material expert, and five lectures in individual small, and large group tests. Data were analyzed with PSA formula and the Wilcoxon Ttest. The result of content validity $87.87 \%$, media validity $90.63 \%$. The result of the small group try-out testing was $88.71 \%$ and the large group try-out testing was $80.71 \%$ with a significance level of $5 \%, \mathrm{df}=88$ obtained $\mathrm{T}$ observed $=\mathbf{2 6 . 5 8}$ and $T$ Table $=1.66$. Thus $T$ is bigger than $T$ Table, meaning that there was a significant difference between the pre-test and posttest. in conclusion, the project-based textbook on instructional media for special needs children is proper and effective.
\end{abstract}

Keywords-Textbooks; Project-Based Learning; Special Needs Children

\section{INTRODUCTION}

Unesa's Department of Special Education (PLB), as one of the institutions responsible for the provision of human resources as educators or special education personnel. Department of PLB has been concentrating on providing teachers as education personnel in special schools or special education[1]. This work ideally cannot be done by just anyone, but in reality, there are still people who do this job does not have a formal education with background special skills required. In essence Special Education (PLB) is majors that print prospective teachers special education for learners who have barriers, limitations or deficiencies both physical, psychic, intellectual, and social. Special Education should always consider four main components: Physical Environment, Teaching Procedures, Teaching Content / Materials and Use of Adaptive Equipment [2].

Since 2001 the government has started pilot school piloting inclusive and in 2004 has become the Directorate of Special Education program under the auspices of the Directorate General of Primary and Secondary Education expressly stated that children with special needs can enjoy education in regular schools. Until now the statement that often appears in the field is about the low ability of Special Teacher Educators especially in preparing media and or learning aids for children with special needs in the learning process.

The essence of the media is interpreted as an intermediary or message delivery from the sender (educator) to the message recipient (learners). Media relevance that matches the characteristics and abilities of learners will increase the likelihood of a significant increase in the knowledge and ability of learners.

Based on the results of empirical observation, obtained learning data shows that, from 89 Students PLB force 20132014, when programming subjects media learning for $\mathrm{ABK}$, having difficulty especially doing the task of making learning media. Most of the students gathered learning media outcomes from downloading on the internet without modification tailored to the characteristics of children with special needs. From the assessment of engaging results, which get the good category $53.58 \%$, enough $39.28 \%$, and less $07.14 \%$. Based on these results it is feared the purpose of learning that provides knowledge and ability to make learning media for crew less than the maximum. It can be said that the implementation related to the making of instructional media still needs to be improved, especially at; (1) lecture system that tends to be teacher-centered, (2) attitudes and interests, (3) quality of work of students who have less relevance in the field

Based on the above, the next thing to be prepared include; (1) facilities and infrastructure that can optimize students learning ability, and (2) ability to create instructional media for children with special needs that are adaptable. To that end, the researcher decided to develop a textbook based on projectbased learning model.

\section{RESEARCH METHOD}

\section{A. Design}

This development research uses Dick and Carey [3] research design, for procedural steps. Dick and Carey's research model suggests that the application of development design principles be tailored to the steps that must be taken in sequence[4]. Information: 


\section{Instructional Goals}

Directorate of Learning and Student Affairs, based on the mandate of the Minister of Education Regulation No. 73 of 2013 need to prepare guidelines Learning Achievements (CP) graduates of courses in universities. Graduate Diploma four (4) or undergraduate applied and undergraduate equivalent with level six (6), formulation of learning achievement arranged in four element that is attitude and value system, workability, knowledge mastering and responsible

\section{Instructional Analysis}

This second step is a procedure for determining skills and knowledge that have relevance and is required by learners to achieve competence and learning objectives. In this step, a concept map will be produced that describes the relationship or relationship of all skills and abilities necessary to achieve the competence or learning objectives.

\section{Entry Behaviors and Learner Characteristics}

Associated with the condition of the students of PLB FIP Unesa are a graduate of SMU / SMK and MA both public and private received as a student of Department of PLB in FIP Unesa through invitation path, SMBTN, and Mandiri path. It is clear that students have different levels of ability and different characteristics.

\section{Performance Objectives}

Directorate General of Higher Education c.q. Directorate of Learning and Student Affairs, based on the mandate of the Minister of Education Regulation No. 73 of 2013 need to prepare guidelines Learning Achievements (CP) graduates of courses in universities. CP study program graduates in addition to the formulation of learning objectives to be achieved and must be owned by all graduates is also a statement of graduate quality. The responsibility of the study program is obliged to have a $\mathrm{CP}$ formulation that can be accounted for either the content, the completeness of the description in accordance with the provisions in the National Standards of Directorate General of Education. High [5].

\section{Criterion-Referenced Test Items}

Assessment and benchmark reference are two things that can not be separated related to the learning process. To find out whether a learning process is done properly is to make an assessment. Practically, an assessment requires a benchmark reference as a standard in the assessors of the learning process undertaken. The new concept according to the Indonesian National Qualification Framework (KKNI) in measuring the learner-centered learning process is a learner-centered assessment. The results of the benchmark reference test provide an indication of how well the learners are able to achieve each learning objective and indicate which components of the learning are working well, and which components need to be revised. The other side of the benchmark reference test allows learners to reflect on themselves by applying the criteria to assess their work independently or as a group.

\section{Instructional Strategy}

Learning activities undertaken by educators are diverse. This research will produce a textbook product about children's learning media with special needs for S-1 students of PLB FIP Unesa with project-based strategy. Thus, the textbook material produced stipulated project-based learning steps that are abbreviated MPjBP (Media-Based Learning Project).

\section{Instructional Materials}

Selection and development of material is realized in the design of learning materials development in the form of textbooks and oriented to the achievement of learning objectives that set in detail, planned and systematic. In accordance with the title of this study is to develop textbooks for subjects of Special Project Based Learning Media in the Department of Special Education, the researchers used project-based learning strategies, while the material described in each chapter (four chapters) in textbooks.

\section{Formative Evaluation}

Formative evaluation is the collection of data and information during the development of learning. Formative evaluation is used to analyze feasibility at each stage. This formative evaluation of this stage reviews the inputs of small group test experts and field tests aimed at obtaining academic and professional inputs related to project-based textbook draft media, in terms of material truth, media (media experts), and facet of effectiveness through individual, small group, and large group trials of prospective users (students).

\section{a. One On One Evaluation:}

Formative evaluation is a test of component or prototype of instructional media to each target systematically undertaken by the developer to obtain information or feedback to refine the media program. Formative evaluations are carried out on target candidates for 1-5 goals.

The purpose of this evaluation is to identify the issues that are considered important in the first draft of the media, then carried out improvements or revisions. This formative evaluation aims to; (1) to know the level of the textbook readability (2) the use of the terms, (3) the language of the presentation, (4) the suitability of the drawings, (5) clarity of clues, and others.

\section{b. A Small Group Evaluation}

A trial or evaluation conducted on a small group of 5-20 people was undertaken to determine whether the revisions that had been done in the earlier stages were effective. In addition, evaluation is also intended to re-identify the remaining weaknesses, as well as to determine the extent to which the draft of this textbook can be easily utilized by students. 


\section{c. A Field Trial Evaluation:}

This trial was performed on one (1) target learning class with no control class. The evaluation of this stage is done by comparing the pretest and posttest results.

\section{Revise the learning process}

In almost all instructional design models, major emphasis will be on formative evaluation concepts, ie on data collection to identify problems and revise draft textbooks. There are two basic types of revisions that can be used to consider learning materials. First is a change made with the content or substance of the material to make it more accurate or more effective as a learning tool. The second is a change related to the procedure used in using the material[6]. Each stage of evaluation before stepping into the next evaluation stage, it will always be done product improvement for continuous improvement.

\section{Summative evaluation}

Summative evaluation is a process of collecting data and information in order to improve the effectiveness of teaching, while summative evaluation is the process of collecting data and information in order to make decisions about the acquisition of learner goals that have been designed. There are two stages of summative evaluation. First, it focuses on the relationship between instruction, interests, and needs.

\section{B. Product Trial Design}

The product trial in this development uses logical validation design with content validity type. Validation is done by experts by way of answering questions provided by researchers and provide criticism or suggestions. This researcher does so that later developed product can be revised or repaired if there are deficiencies and can be tested for empirical validation. According to Sugiyono [7], empirical validation is a validation way that is done by comparing the existing criteria on the instrument with empirical facts that occur in the field. [8] also argues that empirical validation cannot be obtained simply by the preparation of instruments based on provision as well as logical validity, but must also be proven through experience. For more details about the design of the product trial in this research, can be seen in the picture below.

\section{Respondents}

Trial subjects are students who use textbooks that have been developed. The student is a student who is currently studying ABK Learning Media Course class of 2014, a number of 89 students with characteristics (1) have programmed orthopedagogy course, (2) have programmed ABK orthopedagogy course and (3) student motivation level. As a consideration for the development of textbooks, the researchers also validated the textbooks to the relevant experts as well as the collection of responses from the lecturers of course lecturers. Validation will be done with material experts and media experts who must have experience in their respective fields.

\section{Instruments and Data Analysis}

\section{Instruments}

The methods used in this study are structured interviews, questionnaires, and tests. Methods of structured interviews are used to measure the feasibility of textbooks that validated materials expert and media experts and lecturers. The questionnaire method is used to measure the effectiveness of textbooks that have been developed. collecting data for individual trials, small group trials, and large groups. Test methods used to evaluate the success of student learning in one semester of course Media Learning for Children with Special Needs.

\section{Data Analysis}

\section{a. Content analysis}

Content analysis is used to analyze qualitative data obtained from experts in the form of criticism, suggestions, or feedback about the product being developed. The results of this analysis are used as a basis for improving or revising the product for better and can be used in the achievement of optimal learning objectives.

\section{b. Descriptive analysis}

Quantitative data analysis, researchers using descriptive analysis is done based on the results of data from questionnaires that have been distributed to respondents.

Analysis of research data with the descriptive analysis is done by the formula, PSA = Total all alternative answers selected every aspect / Number of alternative answer ideal every aspect x 100. After done Calculation of All Program (PSP) which value is taken from the sum of all value of PSA divided by any aspects, then the outgoing value will be seen in the following criteria:

$81-100=$ very good

$61-80=$ good

$41-60=$ not good

$21-40=$ not good

$0-20=$ not very good

If the PSP calculation results are less than or equal to 60 then the product will be revised or revised in the aspect concerned.

c. Analysis of test results

1. Validity test

The validity of an instrument is a measure that indicates the validity or validity levels of an instrument. A valid or valid instrument has a high validity, otherwise, a less valid instrument has a low validity [9]. The method used in data calculation is using SPSS 20.0 for Windows. To test the correlation significance of sig value. Product 
Moment compared with 0.05 . the statement item is said to be valid or significant if the value of sig. $<0.05$.

\section{Test Reliability}

According to Arikunto [9], reliability shows in a sense that an instrument is quite reliable to be used as a data collection tool because the instrument is good. Meanwhile, to explain that looking for reliability instruments that score is not 1 and 0 , for example, a questionnaire whose score is a range of 1 to 5 or about the form of the description than using the formula Alfacrombach. Reliability testing is done with the help of SPSS 20.0 for Windows software. Instruments have a high degree of reliability if the coefficient values obtained> $0.60[10]$

3. Bivariate Analysis

Bivariate analysis was used to assess the comparability between two paired sample is the difference between pre and post-test using project-based textbooks. The analysis performed is a comparative analysis of two paired samples Test Wilcoxon-test. The test conducted by the author for inferential statistical analysis is as follow:

a. Normality Test

Normality test is a test to determine whether a variable has a normal distribution or not. To test the data distribution normality used Kolmogorov-Smirnov Test where the calculation is done with SPSS 20.0 for Windows software. Interpretation of data normality is calculated by comparing the value of the p-value Kolmogorov-Smirnov Test obtained. Data is said to be normal distribution if with $p$-value $>0,05$.

b. Determine the null hypothesis

H0: Posttest $=$ pretest $=$ There is no significant difference in student test results from before and after using the developed textbook.

H1: Posttest $\neq$ pretest $=$ There is a significant difference in student test results from before and after using the developed textbook.

c. Test the significance of the Wilcoxon test

The Wilcoxon-Test was used to test the significance of the comparative hypothesis of two samples correlated when the data was ordinal. This test is the best test for the comparative test as proposed by Sugiyono, [7]. Testing is done with the help of software SPSS 20.0 for Windows. Data testing criteria are said to be significant or there are significant differences in student test scores between before and after using project-based textbooks if $\mathrm{p}$-value $<0.05$.

\section{RESUlT AND DISCUSSION}

\section{A. Learning Development Process}

In solving the problem of learning in PLB for the course of Learning Media refers to the development model of Dick and Carey [3] covering ten (10) stages. The first stage in the development of textbooks is the identification of the needs of learning tools that must be developed in accordance with the KKNI. The review of the real condition, students have not been able to develop the media according to the characteristic of Children with Special Needs, while the learning time is limited and required for field practice. Hope for the future, (Ideal Condition) students are expected to be able to develop learning media with enough time to understand the characteristics of the media in general and match the characteristics of the ABK.

The results of the feasibility test of textbook materials After the textbook is composed, the researcher performs the validity test of the concept of the textbook's essay to the material expert, the media, and collects the response from the teacher of the lecturer. Data collection is intended to assess whether the developed textbook has been valid or in accordance with the objectives to be achieved and has good specifications for use in learning.

From the data obtained after the calculation of PSA and PSP, with the final value of PSP $=84.83$, it can be concluded that textbooks, when viewed in terms of material, are in a very good category.

From the data obtained after the calculation of PSA and PSP, with the final value of PSP $=80.76$, it can be concluded that textbooks, when viewed in terms of material, are in a good category.

From the data obtained after the calculation of PSA and PSP, with the final value of PSP $=89.29$, it can be concluded that textbooks, when viewed in terms of media, are in a very good category.

Based on the results of material validation test and media validation test, it can be concluded that the project-based textbook that will be used for the PLB students in the subjects of Learning Media for Children with Special Needs is considered feasible as the PLB student handbook in the subject of ABK Learning Media. To reinforce the findings of the above results, also conducted trials on the use of students of the same level and who have characteristics similar to the research objectives.

The test results to determine the feasibility level from the user's point of view of the textbook. Questionnaires that are 
well distributed for individuals, small groups, and large groups are the same. From the data obtained after the calculation of PSA and PSP, with the final value of PSP $=85.67$, it can be concluded that the textbook, when viewed in terms of individual use, is in a very good category.

From the data obtained after the calculation of PSA and PSP, with the final value of PSP $=64.55$, it can be concluded that the textbook, when viewed in terms of small group usage, is in a good category.

From the data obtained after the calculation of PSA and PSP, with the final value of PSP $=83.27$, it can be concluded that the textbook, when viewed in terms of small group usage, is in a very good category.

\section{B. Learning outcomes}

Earlier researchers conducted tests of the target to know the results of student learning about the material before being taught (pre-test). The pre-test is done by using a test instrument. The instrument has been tested for reliability and validity first (the count is attached to the appendix) before being used for the test. Respondent for pre-test is the student of PLB class of the year 2014 number 89 student (student with NIM 14010044006 up to 14010044094). Furthermore, students are required to learn by using textbooks that have been developed. After the implementation of learning ( \pm one semester) using the textbook developed, the researcher conducted Post-Test to the same student. (Value of test result of pre-test and post-test attached). After the researchers get the value of pre-test and post-test test of the target. Researchers perform data calculations using Wilcoxon Signed Rank Test with SPSS 20.0.

Before the calculation of Wilcoxon Signed Rank Test with SPSS 20.0 then, need to do the normality test to ensure that data will be calculated using Wilcoxon Signed Rank Test is not normally distributed. The Wilcoxon Signed Rank Test calculation requires that data should not be normally distributed. The reason for using the Wilcoxon Signed Rank Test is to measure the average difference calculated coming from one group. Normality test in this research using OneSample Test method Kolmogorov Smirnov (KS).

\begin{tabular}{|c|c|c|c|}
\hline \multicolumn{4}{|c|}{ One-Sample Kolmogorov-Smirnov Test } \\
\hline & & Pres Test & Post Test \\
\hline \multicolumn{2}{|l|}{$\mathrm{N}$} & 89 & 89 \\
\hline \multirow{2}{*}{$\begin{array}{l}\text { Normal } \\
\text { Parameters } \\
\text { a,b }\end{array}$} & Mean & 53,76 & 78,03 \\
\hline & Std. Deviation & 6,583 & 4,684 \\
\hline \multirow{3}{*}{$\begin{array}{l}\text { Most } \\
\text { Extreme } \\
\text { Differences }\end{array}$} & Absolute &, 379 & ,202 \\
\hline & Positive & ,379 & ,202 \\
\hline & Negative &,- 216 &,- 202 \\
\hline \multicolumn{2}{|c|}{ Kolmogorov-Smirnov Z } & 3,577 & 1,906 \\
\hline \multicolumn{2}{|c|}{ Asymp. Sig. (2-tailed) } &, 000 &, 001 \\
\hline \multicolumn{4}{|c|}{ a. Test distribution is Normal. } \\
\hline \multicolumn{4}{|c|}{ b. Calculated from data. } \\
\hline
\end{tabular}

The table above shows that the Kolmogorov-Smirnov statistical value obtained has a Kolmogorov-Smirnov $Z$ value of 3.577 and 1.906 while the Asymp value. Sig. (2-tailed) 0,000 and 0.001 because of the value of Asymp. Sig. (2-tailed) obtained more than 0.05 it can be stated that the data is not normally distributed. After the data is not normally distributed, then calculated Wilcoxon Signed Rank Test SPSS 20.0. Here are the calculations.

Test Statistics

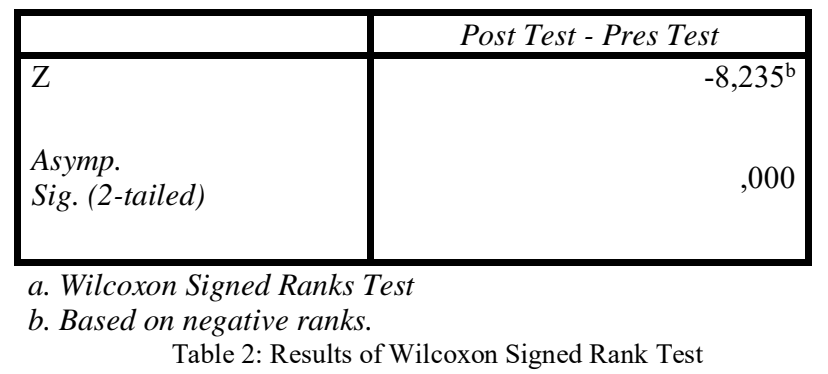

\section{CONCLUSION}

1. Textbook developed and tested by expert material validation with eight aspects/indicators consisting of, material suitability (79.17) and material depth $(76,79)$ obtained good category. Furthermore, for material upgrades (87.5), encouraging curiosity (87.5), presentation techniques (92.5), presentation supporters (83.33), Presentation in learning (84.38), and Thinking Ground Flow $(87,5)$ very good category. The calculation result of the whole program assessment (PSP) which can be from the sum of all aspect values divided by the number of aspects also shows the value of 84.83 which means very good. Based on the categorical value and the calculation of PSP is concluded that the material contained in textbooks for the course Media ABK Learning declared feasible.

2. From the recapitulation of media expert validation test with six indicators comprising, the textbook size 93,75, the cover design 79.17, the design of content 80.76, Lucas 75 , communicative, dialogical, and elective 79.17 , conformity with the rules language 75 . The results of the calculation of the whole program assessment (PSP) which can be from the sum of all aspect values divided by the number of aspects also shows the value of 84.83 which means very good. The results of the calculation of the whole program assessment (PSP) shows a good value of 80.76. The conclusion that can be taken that the textbook developed is good and declared feasible.

3. The response is given from the lecturers for the subjects; Material compatibility (90), Material upgrades (88.33), Presentation supporters (92.5), Presentation in learning (86.25), Suitability of thought flow (87.14), Language (93.33), and interest 87.5), and PSP calculation (89.29). From the result of the lecturer's lecturer's response stated very well and deserve to be used as a handbook for the student of PLB for a subject of Learning Media ABK. It is very rational because during this time PLB students do not have a guidebook to be used as a reference to producing learning media that has characteristics for children with special needs. 
4. Furthermore, from the results of individual trials, small groups, and large groups obtained results;

a. individual student test obtained excellent results. The conclusion was obtained from the data showing the suitability of the material (85), the language aspect $(86,67)$, the interesting aspect $(92,5)$, which then calculated PSP get result 85,67.

b. small group test resulted in good appraisal, collected data such as material suitability $(62,5)$, linguistic aspect $(67,04)$, interest aspect $(64,06)$, and the result of PSP calculation $(64,55)$.

c. and so for large group test results showed excellent results because of the value of material conformity (84.01), language aspects (84.14), interest aspect (81.65), and PSP (83.27).

Of all the test results that have been implemented, the textbook developed can be said to be good and worthy to be used in the learning process of the student PLB Faculty of Education Unesa.

Based on the results of data analysis of pre-test and posttest of students, learning using textbook developed proved effective and able to improve student learning outcomes. This is evidenced by the increase of post-test students if when analyzed using the t-test formula and using 5\% significance level. The calculation results show that the value of 26.58 with table $=1.66$ derived from d.b $=89-1=88$. Thus it can be said that Textbook Learning Media ABK has a high effectiveness.

\section{REFERENCES}

[1] U. Unesa, Buku Pedoman Perkuliahan PLB, FIP, PLB,. Surabaya: Unesa Unipress, 2012.

[2] M. Sugiarmin, "Pengembangan Teknologi Asistif bagi Anak Berkebutuhan Khusus Dalam Setting Pendidikan Inklusif," Univ. Pendidik. Indones., 2012.

[3] W. Dick, L. Carey, and J. O. Carey, "The systematic design of instruction," 2005

[4] B. B. Seel and C. Rita, "Richey. 1994," Teknol. Pembelajaran Defin. dan Kawasannya.

[5] R. Indonesia, Peraturan pemerintah RI Nomor 19 Tahun 2005 Tentang standar nasional pendidikan. Cipta Jaya, 2005.

[6] B. S. N. Pendidikan, "Kurikulum Tingkat Satuan Pendidikan," Jakarta Dep. Pendidik. Nas., 2006.

[7] P. Sugiyono, "Dr. 2010," Metod. Penelit. Kuantitatif, Kualitatif, dan R\&D. Bandung CV Alf.

[8] A. Suharsimi, "Prosedur penelitian suatu pendekatan praktik," Jakarta: Rineka Cipta, 2006.

[9] S. Arikunto, "Research Procedure A Practical Approach," Ed. Revis. Jakarta Rineka Cipta, 2010.

[10] G. S. Hadi, R. Varianto, B. Trilaksono, and A. Budiyono, "Autonomous UAV system development for payload dropping mission," J. Instrumentation, Autom. Syst., vol. 1, no. 2, pp. 22-72, 2014 